\title{
Toluene oxidation: UV irradiation vs. ferrates
}

\author{
Lucia Fašková, Daniela Pavúková, Emília Mališová, \\ Ladislav Štibrányi, Ján Híveš
}

\author{
Department of Inorganic Technology, Institute of Inorganic Chemistry, Technology and Materials, \\ Faculty of Chemical and Food Technology, Slovak University of Technology, \\ Radlinského 9, 81237 Bratislava, Slovakia \\ lucia.faskova@stuba.sk
}

\begin{abstract}
Novel technologies for organic pollutants degradation have been studied to cope with extensive water pollution. In this work, the use of ultraviolet degradation and potassium ferrate as possible oxidation tools for toluene, a widely used industrial chemical, degradation is proposed. In the experiment with ultraviolet irradiation, a low-pressure mercury lamp was used to generate a single line electromagnetic radiation with the wavelength of $254 \mathrm{~nm}$. Maximal degradation efficiency achieved after 55 minutes of irradiation was $67.1 \%$. In the experiments with potassium ferrate, the highest degradation efficiency was $71.2 \%$ at the concentration of $10 \mathrm{mg} / \mathrm{L}$ of ferrate (VI) anion.
\end{abstract}

Keywords: degradation, ferrate, toluene, UV irradiation

\section{Introduction}

Environmental pollution by organic chemicals represents one of the major concerns of today. Continuous manufacturing of petrochemicals and ongoing increase in mobility result in increased concentrations of substances such as benzene, toluene, chlorobenzene, polyaromatic hydrocarbons and many others in groundwater (Qiu et al., 2016). For instance, the amount of water needed to process crude oil is estimated to be 0.4 to 1.6 -fold per unit of crude oil. Considering the amount of crude oil processed worldwide, 5.34 to 21.37 million cubic metres of wastewater are daily generated from the oil industry (Singh and Singh, 2019). Refineries are equipped with wastewater treatment plants, but their efficiency is not absolute and significant amounts of pollutants reach the water systems. In France, daily estimated release of toluene from one particular petrochemical industry site reached up to almost $26 \mathrm{~kg}$ in absolute terms. Nonetheless, petrochemical industry is not the sole source of toluene pollution. The occurrence of toluene can also originate from metalworking, paint manufacture and use, plastics and fibres industry, tanning, textile dying, papermills, surface treatment or traffic (European Chemicals Bureau, 2003). Another anthropological source of environmental pollution is through leakages in product pipelines (van der Meijde et al., 2009) or at gas stations (dos Anjos Santos et al., 2013). Toluene is a volatile compound and thus it is found in underground water near industrial sites and rarely in drinking water (Leutsch and Berkow, 2010). However, even evaporated toluene, or other volatile organic compounds, can re- enter water sources via raindrops or snowflakes (Lei and Wania, 2004). Possible sources of toluene also imply natural sources, e.g. incomplete combustion during forest burning (Barboni et al., 2009), petroleum seepage or weathering of exposed coal from petroliferous rocks (Barberes et al., 2018). There is no doubt that toluene has an acute and chronic ecotoxicological impact on model organisms in magnitudes of milligrams per litre. However, there is also evidence of sublethal effects on animals, for example on the enzyme activity of fish affecting their metabolism (Dange and Masurekar, 1981), a change in fish haematological parameters (Inyang et al., 2018) or even oxidative stress and DNA damage in earthworms (Liu et al., 2010). Water pollutants are never present as single compounds but as complex mixtures and there is evidence of the synergistic effect of mixtures (Faust et al., 2003) and more authors observed also the additive effect ( $\mathrm{Li}$ et al., 2013; Singh et al., 2010; Sato and Takajima, 1979). However, these compounds should not be present in water or the environment, which is also asserted by the European Union within Directive 2008/105/EC.

The scientific community is considerably engaged with this topic while searching for efficient means for the degradation of these dangerous substances. Various methods of organic substances degradation, including mainly incorporation of hydroxyl radical, e.g. ozonation (Kuo and Chen, 1996; Sekiguchi et al., 2003), electrooxidation (Farinos et al., 2017; Rabaaoui et al., 2013), catalysed photooxidation (Xu et al., 2020; Kim et al., 2019) or Fenton reactions (Huling et al., 2011; Ramteke and Gogate, 2015), have been investigated. In the presented 
work, degradation of toluene using ultraviolet (UV) irradiation and potassium ferrate $\left(\mathrm{K}_{2} \mathrm{FeO}_{4}\right)$, which is considered to be an environmentally friendly oxidant, is presented.

\section{Materials and Methods}

Used chemicals included toluene p.a. (Centralchem s.r.o, Slovakia), potassium ferrate $(70 \%$, prepared internally according to the procedure published by Kubiňáková et al., 2015) and distilled water (prepared internally by atmospheric distillation).

Instrumental system for the degradation using UV irradiation comprised a reactor equipped with a low-pressure mercury lamp, which provided single line spectra with the wavelength of $254 \mathrm{~nm}$ at the power of $10 \mathrm{~W}$.

As suitable analytical methods, high-performance liquid chromatography (HPLC) and gas chromatography coupled with mass spectrometry (GC-MS) were chosen. Prior to the GC-MS analysis, the samples were subjected to solid phase extraction (SPE). Operating conditions of HPLC: HPLG Thermo Fisher UltiMate 3000 Rapid Separation with UltiMate DAD detector working at $254 \mathrm{~nm}$; column: SUPELCOSIL ${ }^{\text {TM }}$ LC-18 with dimensions of $25 \mathrm{~cm} \times 4.6 \mathrm{~mm} \times 5 \mu \mathrm{m}$; mobile phase: methanol:water ratio of $85: 15$ in isocratic mode; mobile phase flow: $1 \mathrm{~mL} / \mathrm{min}$.

Operating conditions of GC-MS: GC Agilent Technologies 7890A equipped with mass spectrometer Agilent Technologies 5975C, column: ZB-FAME with dimensions of $30 \mathrm{~m} \times 0.25 \mathrm{~mm} \times 0.20 \mu \mathrm{m}$; carrier gas: helium; carrier gas flow: $1.6 \mathrm{~mL} / \mathrm{min}$; temperature program: initial temperature of $80^{\circ} \mathrm{C}$ held for one minute followed by a gradient of $10^{\circ} \mathrm{C} / \mathrm{min}$ up to $280^{\circ} \mathrm{C}$ held for 10 minutes; injector temperature: $280^{\circ} \mathrm{C}$; electron ionization: at $70 \mathrm{eV}$.

\section{UV irradiation experiments}

Stock solutions of toluene in the amount of $250 \mathrm{~mL}$ and the concentration of $0.1,0.3$ and $0.5 \mathrm{~mL} / \mathrm{L}$ were prepared, quantitatively transferred into the reactor and irradiated at the wavelength of $254 \mathrm{~nm}$ for $55 \mathrm{~min}$. Temperature was kept at the value of $20^{\circ} \mathrm{C}$ using cooling water, and the system was stirred using a glass stirrer. UV radiation renders photochemical oxidation during which hydroxylated benzenes or other products of photooxidation can occur (Oppenlander, 2003). Samples of the reaction mixture were taken in the time intervals of $10,20,30$ and $55 \mathrm{~min}$ and analysed immediately after sampling using HPLC to prevent further photochemical or following reactions. The irradiated solution was processed using SPE and analysed using GC-MS to determine the photoreaction products.

\section{Experiments using ferrates}

A stock solution of toluene with the concentration of $0.1 \mathrm{~mL} / \mathrm{L}$ was prepared. Five beakers were each filled with $100 \mathrm{~mL}$ of this stock solution and potassium ferrate was added to achieve ferrate anion concentration of $1,3,5$ and $10 \mathrm{mg} / \mathrm{L}$. The last sample contained the equimolar amount of the ferrate anion, which equals to $186 \mathrm{mg} / \mathrm{L}$ of pure potassium ferrate to toluene. Typical violet colouring of the ferrate anion appeared in the solution immediately after adding the potassium ferrate powder. The ferrate anion is a strong oxidant agent with the standard redox potential of $2.2 \mathrm{~V}$ against the standard hydrogen electrode in the acidic environment. After its reduction from $\mathrm{Fe}^{\mathrm{VI}}$ to $\mathrm{Fe}^{\mathrm{III}}$, the solution changes its colour to slightly yellow, indicating the end of the reaction. The solution was afterwards analysed using HPLC.

\section{Results and Discussion}

\section{Toluene degradation using UV irradiation}

In the first ten minutes, UV radiation degraded from $35.4 \%$ to almost $40 \%$ of the initial amount of toluene, as shown in Fig. 1. At the end of the UV irradiation, for 55 minutes, the maximal degradation efficiency of $67.1 \%$ in the sample with initial toluene concentration of $0.5 \mathrm{~mL} / \mathrm{L}$ was achieved. The degradation efficiency was calculated as a relative decrease in the initial toluene concentration; therefore, quantitative toluene conversion to photochemical reaction products is obtained. Visually, the transparent toluene solution changed its colour to slightly yellow, implying the change in the structure of the molecule. Similar results were obtained by another research group who were able to degrade approx. $75 \%$ of toluene in 60 minutes of irradiation using a $500 \mathrm{~W}$ highpressure mercury lamp (Daifullah and Mohamed, 2004). However, the high-pressure mercury lamp provides multi line spectra with seven main peaks (Oppenlander, 2003). The most important peak at the wavelength of $254 \mathrm{~nm}$, which is most suitable for the degradation of toluene, is not pronounced considering the other six peaks. Lower UV light intensity can be compensated by higher power of the lamp, but this is connected with higher costs due to energy consumption. Moreover, high-pressure mercury lamps are operating at the electricity-tophoton (radiant) efficiency below $20 \%$. In comparison, low-pressure lamps operate at the radiant efficiency of $40 \%$ to $60 \%$. The epiphenomenon of low radiant efficiency is the enormous production of heat, which means that such a system needs an effective cooling system and even higher costs (Evans et al., 2013). 


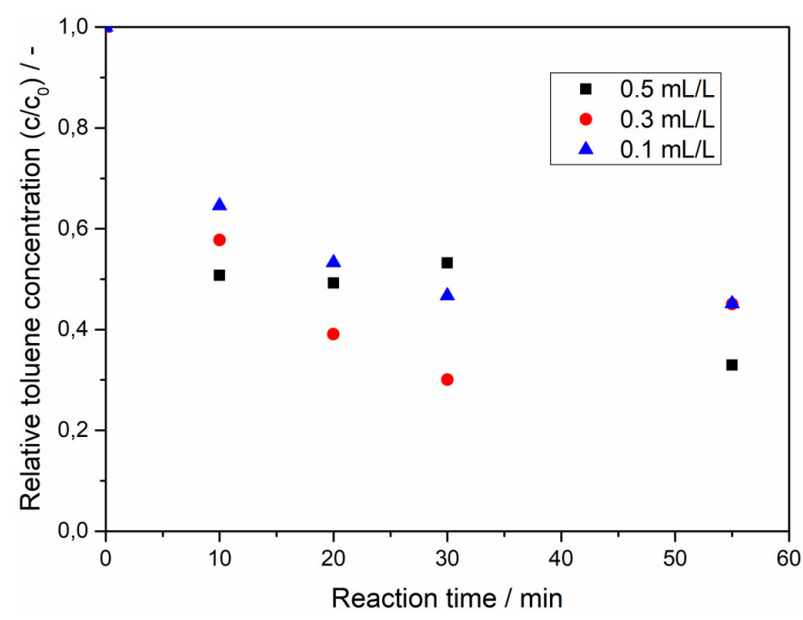

Fig. 1. Decrease in relative toluene concentration during $254 \mathrm{~nm}$ UV irradiation of samples with the initial toluene concentration of $0.1 \mathrm{~mL} / \mathrm{L}$, $0.3 \mathrm{~mL} / \mathrm{L}$ and $0.5 \mathrm{~mL} / \mathrm{L}$.

HPLC analysis showed four degradation products. All of them eluted on the reverse phase column earlier as toluene, which suggests higher polarity in regard to the former molecule. After processing the sample using SPE, it was analysed using GC-MS. The analysis proved six photooxidation products, namely benzaldehyde, benzyl alcohol and all three isomers of cresol (ortho-, meta-, para-), which is in good accordance with the theory. The theory implies the incorporation of dissolved oxygen from the solution via a radical reaction mechanism (Oppenlander, 2003). Considering ecotoxicological properties, all reaction products are, according to applicable lethal doses data provided by the European Chemicals Agency, less toxic than toluene.

\section{Toluene degradation using potassium ferrate}

Oxidation strength of ferrates depends on the solution $\mathrm{pH}$. In acidic media, the ferrate anion has a standard redox potential of $2.20 \mathrm{~V}$ in respect to standard hydrogen electrode. In contrast, this value drops to $0.72 \mathrm{~V}$ under basic conditions. During the reduction of $\mathrm{Fe}^{\mathrm{VI}}$ to $\mathrm{Fe}^{\mathrm{III}}$, hydroxide anions are created. The corresponding reaction and more information can be found in Híveš et al. (2016). Therefore, finding the appropriate concentration of ferrates is essential to reach the highest degradation efficiency at the lowest cost. The $\mathrm{pH}$ value of samples was measured right after potassium ferrate addition (denoted as $0 \mathrm{~min}$ ) and continuously during the oxidation in the time interval of 10 minutes, up to 30 minutes. The obtained data are graphically summarised in Fig. 2.

After the content analysis on HPLC, only two degradation products appeared in the chromatogram. As presumed, both with higher polarity than the toluene molecule. The highest degradation efficiency was achieved at $10 \mathrm{mg} / \mathrm{L}$ of ferrates (71.2 \%). Nonetheless, even at ten-fold lower ferrate concentration, the oxidation was successful to a non-negligible extent. Degradation efficiencies were as follows: $52.5 \%$ at $1 \mathrm{mg} / \mathrm{L}, 58.4 \%$ at $3 \mathrm{mg} / \mathrm{L}, 64.3 \%$ at $5 \mathrm{mg} / \mathrm{L}, 71.2 \%$ at $10 \mathrm{mg} / \mathrm{L}$ and $56.0 \%$ at equimolar amount of the ferrate anion. It is apparent that the highest (equimolar) concentration of ferrates resulted in almost the lowest degradation efficiency while the $\mathrm{pH}$ value increases. This phenomenon is in accordance with the theory and was also observed by Minetti et al. (2017) who achieved maximal degradation efficiency under slightly acidic (54\%) and neutral pH (56\%) conditions. In the basic media, the degradation efficiency decreased to $43 \%$ (Minetti et al., 2017). However, no degradation products were reported and the paper claims that the toluene molecule was completely mineralised after 40 days of ferrate application.

\section{Acknowledgement}

This work was financially supported by the Ministry of Education, Science, Research and Sport of the Slovak Republic under the projects OP VaV ITMS 26240120034,



Fig. 2. Effect of potassium ferrate on $\mathrm{pH}$ during toluene oxidation. 
VEGA 1/0343/19, APVV-17-0183 and the Young Researchers Grant within the Slovak University of Technology (ElCapFe).

\section{References}

Barboni T, Cannac M, Pasqualini V, Simeoni A, Leoni E, Chiaramonti N (2009) Int J Wildland Fire 19(5): 606-612.

Barberes GA, dos Reis RP, Spigolon ALD, Fonseca PE, de Mello CB, Barata MT (2018) Geosci. 8(1), 9.

Daifullah AHAM, Mohamed MM (2004) J. Chem. Technol. Biotechnol. 79: 468-474.

Dange AD, Masurekar VB (1981) J. Biosci. 3(2): 129-134. dos Anjos Santos M, Távora BE, Koide S, Caldas ED (2007) Rev. Saúde Públ 47(2): 335-344.

European Chemicals Bureau (2003) European Union Risk Assessment Report Toluene. Office for Official Publications of the European Communities, Italy.

Evans R, Douglas P, Burrows H (2013) Applied Photochemistry. Springer, United States.

Faust M, Altenburger R, Backhaus T, Blanck $\mathrm{H}$, Boedeker W, Gramatica P, Hamer V, Scholze M, Vighi M, Grimme LH (2003) Aquat Toxicol 63(1): 43-63.

Farinos RM, Ruotolo LAM (2017) Electrochim. Acta 224: 32-39.

Híveš J, Gál M, Kerekeš K, Kubiňáková E, Mackulak $\mathrm{T}$ (2016) Electrochemical Ferrates(VI) Preparation and Wastewater Treatment. Ferrites and Ferrates: Chemistry and Applications in Sustainable Energy and Environmental Remediation. 221-240. American Chemical Society, Washington DC.

Huling SG, Hwang S, Fine D, Ko S (2011) Water Res. 45(16): 5334-5342.

Inyang IR, Puanoni AR, Izah SC (2018) MOJ Toxicol. 4(6): 440-444.

Kim SR, Ali I, Kim JO (2019) Appl. Surf. Sci. 477: 71-78.

Kubiňáková E, Kerekeš K, Gál M (2015) J Appl Electrochem 45: 1035-1042.
Kuo CH, Chen SM (1996) Ind. Eng. Chem. Res. 35: 3973-3983.

Lei YD, Wania F (2004) Atmos. Environ. 38(22): 3557-3571.

Li X, Zhou Q, Luo Y, Yang G, Zhou T (2013) Environ Sci Pollut Res Int 20(2): 957-966.

Liu Y, Zhou Q, Xie X, Lin D, Dong L (2010) Ecotoxicology 19: $1551-1559$.

Leutsch F, Bertkow M (2010) A short primer on benzene, toluene, ethylbenzene and xylenes (BTEX) in the environment and in hydraulic fracturing fluids. Available at: https://environment.des.qld.gov.au/ data/assets/pdf_file/0020/87140/btex-report.pdf (Accessed 6 May 2020).

Minetti RCP, Macano HR, Britch J, Allende MC (2017) J. Hazard. Mater. 324: 448-456.

Oppenlander T (2003) Photochemical Purification of Water and Air. Wiley-VCH, Darmstadt.

Qiu L, Dong Z, Sun H, Li H, Chang C (2016) Water Environ Res 88: 1855-1875.

Rabaaoiu N, Moussaoui Y, Allagui MS, Ahmed B, Elaloui E (2013) Sep. Purif. Technol. 107: 318-323.

Ramteke LP, Gogate PR (2015) J Ind Eng Chem 28: 247-260.

Sato A, Takajima T (1979) Toxicol Appl Pharmacol 48(2): 249-256.

Sekiguchi K, Sanada A, Sakamoto K (2003) Catal Commun 4(5): 247-252.

Singh MP, Ravi Ram K, Mishra M, Shrivastava M, Saxena DK, Kar Chowdhuri D (2010) Chemosphere 79(5): 577-587.

Singh RL, Singh RP (2019) Advances in biological treatment of industrial waste water and their recycling for a sustainable future. Springer, Singapore.

van der Meijde M, van der Werff HMA, Jansma PF, van der Meer FD, Groothuis GJ (2009) Int J Appl Earth Obs 11(1): 77-82.

Xu T, Zheng H, Zhang P (2020) J. Hazard. Mater. 388: 121746 . 